\title{
Spider assemblages on tree trunks in primeval deciduous forests of the Białowieża National Park in eastern Poland
}

\author{
Marzena Stańska, Tomasz Stański \& Joanna Hawryluk
}

Stańska, M., Stański, T. \& Hawryluk, J. 2018: Spider assemblages on tree trunks in primeval deciduous forests of the Białowieża National Park in eastern Poland. — Entomol. Fennica 29: 75-85.

We analysed spider assemblages of tree trunks in an oak-lime-hornbeam forest, an ash-alder riparian forest and an alder carr in the primeval stands of the Białowieża National Park. Spiders were collected from June 1998 to October 2000 using bark traps. A total of 2,182 spider individuals, belonging to 43 species and 14 families was collected. The forest types differed in the spider abundance and species richness. The differences probably resulted from different tree species and different environmental conditions in the forest types. The most numerous species in oak-lime-hornbeam forest and in alder carr was Amaurobius fenestralis, whereas Anyphaena accentuata was the most abundant species in ash-alder riparian forest. Four species (Amaurobius fenestralis, Anyphaena accentuata, Segestria senoculata and Neriene montana) were collected in each month (March-October), whereas most species were recorded sporadically or in some periods.

M. Stańska \& T. Stański, Siedlce University of Natural Sciences and Humanities, Faculty of Natural Sciences, Department of Zoology, ul. B. Prusa 12, 08-110 Siedlce,Poland; E-mails: marzena.stanska@uph.edu.pl,tomasz.stanski@uph. edu.pl

J. Hawryluk, ul. Walecznych 3/22, 08-300 Sokołów Podlaski, Poland; E-mail: jhawryluk@o2.pl

Received 9 May 2017, accepted 10 October 2017

\section{Introduction}

Trees as large complex structures constitute an important habitat for many groups of invertebrates (Nicolai 1986, Koponen et al. 1997, Floren 2008, Sebek et al. 2016). They provide a variety of unique microhabitats (i.e. foliage, branches, trunks, dead parts of wood, crevices and cavities), diversified in terms of structure, food availability and microclimatic conditions (Prinzing 2005, Michel \& Winter 2009, Regnery et al. 2013, Wardhaugh et al. 2013). One of the most distinctive microhabitats of a tree is its trunk. As a habi- tat for invertebrates, the bark mainly constitutes the trunk features. The bark differs among tree species and its structure determines physiological properties (e.g. thermal conditions) and consequently affects bark-dwelling arthropods (Nicolai 1986, 1989, 1995).

Bark-dwelling arthropod communities are very diversified and spiders are one of the dominant groups among them (Nicolai 1989, 1993, Koponen et al. 1997, Koponen 2004). Szinetár and Horváth (2005) informed about 298 spider species from Europe in their review of publications on tree trunk spiders. Blick (2011) reported 
a total of 334 spider species recorded on bark from Germany, i.e. one third of the spider fauna in this country. This seems impressive but most of the species are rather facultative trunk-dwellers or accidental visitors (Wunderlich 1982, Horváth \& Szinetár 2002, Szinetár \& Horváth 2005). Despite the richness of the spider fauna inhabiting tree trunks, it is not a frequent subject of research compared to other habitats settled by spiders. According to Blick (2011), the knowledge about the tree trunk fauna in forests of Central Europe is at the level of 5\% compared to the epigeal fauna.

A considerable part of the studies in Europe has been conducted in Hungary (e.g. Bogya et al. 1999, Horváth \& Szinetár 2002, Horváth et al. 2005), but some of them also in Finland (Koponen et al. 1997, Koponen 2008,), Germany (Blick 2011) and the Czech Republic (Machač \& Tuf 2016). Many of the studies devoted to spider assemblages on tree trunks concern habitats created by man or subjected to human impact, like orchards (Koślińska 1967, Pekár 1999, Korenko \& Pekár 2010), planted trees or plantations of trees (Horváth \& Szinetár 1998, Horváth et al. 2004) and urban areas (Horváth \& Szinetár 2002, Machač \& Tuf 2016). Although there have been studies from natural areas (Weiss 1995, Blick 2011), there are no publications (to our knowledge) describing the spider fauna of tree trunks in forests preserved in primeval conditions, like those in Białowieża Forest, eastern Poland. Admittedly, there are some studies conducted in Białowieża Forest on canopy spiders, but their scope covered not only trunks but also the whole tree crowns and they were conducted in managed forest stands (Otto \& Floren 2007, Mupepele et al. 2014).

Białowieża Forest, the largest and best-preserved natural forest complex in the European Lowland, is a refuge for many rare or threatened plant and animal species (Gutowski \& Jaroszewicz 2004, Okołów et al. 2009). The primeval forest stands protected in the Białowieża National Park are distinguished from other European temperate forests by many features (e.g. diverse forest communities, multi-storey profiles of forest stands, very high trees, large amounts of dead wood) and should be treated as a model of primeval conditions (Tomiałojć 1991, Wesołowski 2007). While spiders have been a focus of fau- nistic and ecological research in this area (Karpiński 1956, Łęgowski 2001, Staręga \& Kupryjanowicz 2001, Stańska 2007, Stańska et al. 2016), no research has yet been published on spider assemblages on tree trunks.

The primary objectives of our study were: 1) to determine the species diversity of spider assemblages on tree trunks in alder carr, ash-alder riparian forest and oak-lime-hornbeam forest, 2) to compare the number of spider individuals and number of spider species between the three analysed forest types and 3) to assess how these variables change in time from month to month during the sampling period.

\section{Materials and methods}

\subsection{Study area}

The study was conducted in the Białowieża National Park (BNP), which is the best-preserved part of Białowieża Forest, a large forest complex $\left(1,500 \mathrm{~km}^{2}\right)$ situated on the border between Poland and Belarus. The major part of BNP, protected since 1921, has never been logged and possesses many characteristics of primeval forest, like multi-storey, mixed-species and unevenaged tree stands with a large amount of dead wood (Tomiałojć 1991, Bobiec 2002).

Our study plots, rectangles of about $40 \times 20 \mathrm{~m}$ in size, were located in three primeval deciduous forest stands: oak-lime-hornbeam forest (TilioCarpinetum), ash-alder riparian forest (CircaeoAlnetum) and alder carr (Carici elongataeAlnetum) (Fig. 1). The first type of forest stands, the oak-lime-hornbeam forest, covers the largest area of BNP and is the most diverse in the terms of structure, with many tree species. Lime (Tilia cordata Mill.), hornbeam (Carpinus betulus L.), Norway spruce (Picea abies (L.) H. Karst), pedunculate oak (Quercus robur L.), ash (Fraxinus excelsior L.) and elms (Ulmus spp.) are the most numerous in this forest type.

Our plot was located in the poorer type of the oak-lime-hornbeam forest, Tilio-Carpinetum calamagrostietosum, which is characterised by poor forest-floor vegetation and the dominance of hornbeam, oak and spruce. The second plot was located in the ash-alder riparian forest, which is a 
Fig. 1. Location of the study plots in the Białowieża National Park in eastern Poland, each plot representing a different forest type: Ac - alder carr; Olh oak-lime-hornbeam forest; $\mathrm{Rf}$ - ash-alder riparian forest.

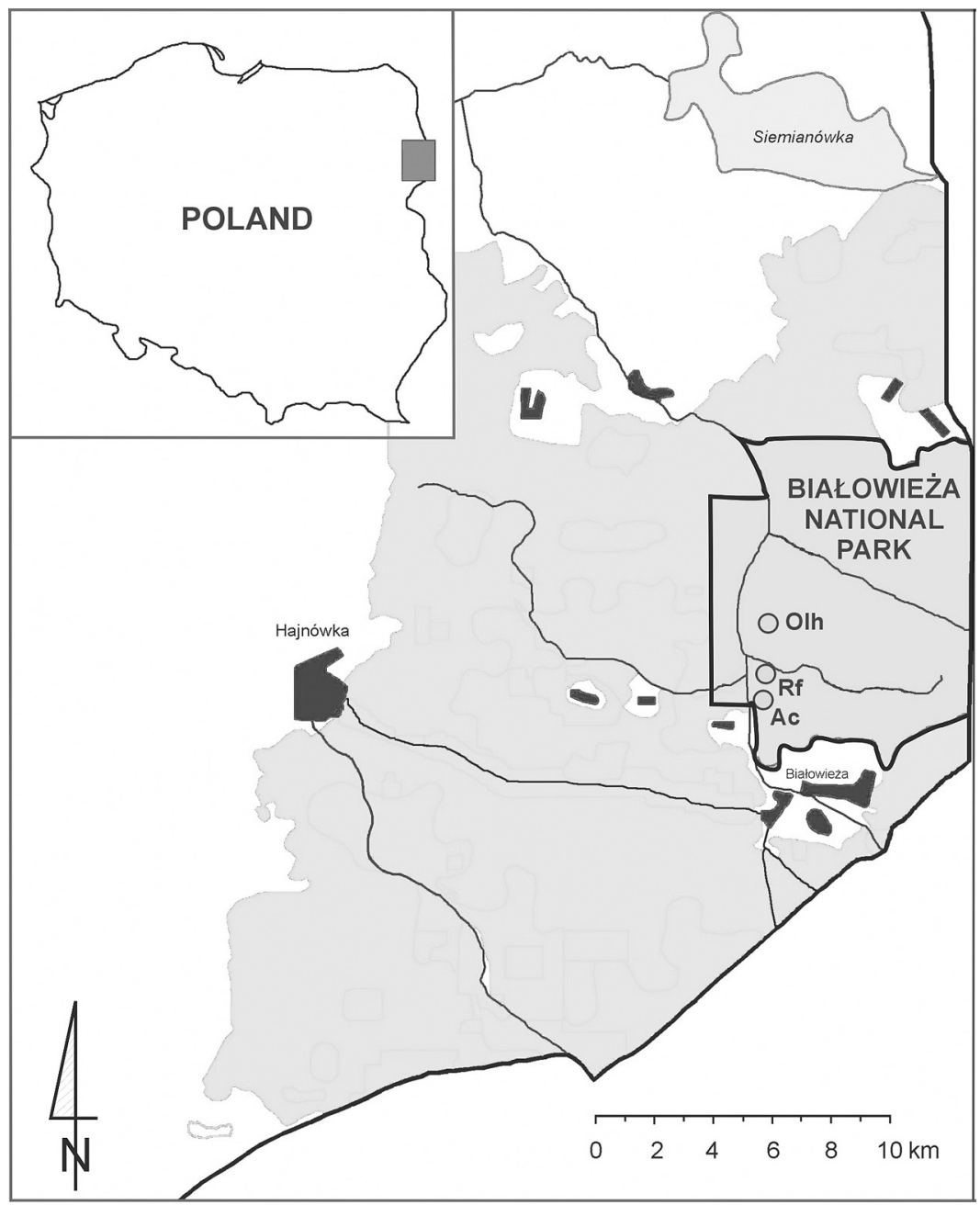

typical plant community growing along the watercourses. It consisted of black alder (Alnus glutinosa Gaertn.) and ash, with some admixture of Norway spruce. The vegetation of the forest floor in the ash-alder riparian forest was the most luxuriant among the analysed plots. The third plot was located in alder carr, which also occupies marshy, fertile habitats but its existence is determined by a permanently high water level without outflow. This forest type is characterised by a well-developed hummock-hollow structure in the forest floor. Trees (the most common being black alders, ashes and Norway spruces) grow in clumps on the hummocks, while the hollows (with water present for a considerable part of the year) are dominated by marshland plant species (Pawlaczyk 2009).

\subsection{Spider samples and statistical analysis}

Spiders were collected from June 1998 to October 2000 on the three plots located each in a different type of deciduous forest stand. Samples were collected once a month (excluding November, December, January and February) from trunk traps made of $25 \mathrm{~cm}$ wide corrugated cardboard, which were located at $1.5 \mathrm{~m}$ above the ground on tree trunks. We placed 5 traps, in a distance of 7-10 m from each other, in each forest type on living trees of a similar diameter selected from the dominant species within each stand. In the case of alder carr, those were three black alders and two spruces, in the ash-alder riparian forest two black alders, two ashes and one spruce, and in the oak-lime-hornbeam forest one lime, 
Table 1. Spider species collected on tree trunks in deciduous forest stands of the Białowieża National Park (spider families and species in alphabetical order). In statistical analyses, only adult specimens identified to species level were included. Roman letters in last two columns mean months in which spiders were recorded. Abbreviations: Ac - alder carr, Olh - oak-lime-hornbeam forest, $\mathrm{Rf}$ - ash-alder riparian forest, ad - adult spider individuals, juv - juvenile spider individuals.

\begin{tabular}{|c|c|c|c|c|c|c|c|c|}
\hline & \multicolumn{2}{|c|}{$A c$} & \multicolumn{2}{|c|}{ Olh } & \multicolumn{2}{|c|}{ Rf } & \multicolumn{2}{|c|}{ Months } \\
\hline & $\mathrm{ad}$ & juv & ad & juv & ad & juv & $\mathrm{ad}$ & juv \\
\hline \multicolumn{9}{|l|}{ Agelenidae } \\
\hline $\begin{array}{l}\text { Coelotes atropos } \\
\text { (Walckenaer, 1830) }\end{array}$ & 2 & 2 & 25 & 6 & 2 & & $\mathrm{~V}-\mathrm{X}$ & VI, VII \\
\hline \multicolumn{9}{|l|}{ Amaurobiidae } \\
\hline $\begin{array}{l}\text { Amaurobius fenestralis } \\
\text { (Ström, 1768) }\end{array}$ & 62 & 123 & 124 & 256 & 2 & 3 & III-X & III, V-X \\
\hline \multicolumn{9}{|l|}{ Anyphaenidae } \\
\hline $\begin{array}{c}\text { Anyphaena accentuata } \\
\text { (Walckenaer, 1802) }\end{array}$ & 6 & 98 & 8 & 102 & 12 & 53 & $\mathrm{~V}, \mathrm{VI}, \mathrm{VIII}, \mathrm{X}$ & III,IV,VIII-X \\
\hline \multicolumn{9}{|l|}{ Araneidae } \\
\hline $\begin{array}{l}\text { Araneus diadematus } \\
\text { Clerck, } 1757\end{array}$ & & & & 1 & & & & $x$ \\
\hline $\begin{array}{l}\text { Cyclosa conica } \\
\text { (Pallas, 1772) }\end{array}$ & & 1 & & & & & & VIII \\
\hline $\begin{array}{l}\text { Leviellus stroemi } \\
\quad \text { (Thorell, 1870) }\end{array}$ & 4 & & & & & & III, VIII-X & \\
\hline $\begin{array}{l}\text { Nuctenea umbratica } \\
\text { (Clerck, 1757) }\end{array}$ & 1 & & & & & & $x$ & \\
\hline \multicolumn{9}{|l|}{ Clubionidae } \\
\hline $\begin{array}{c}\text { Clubiona lutescens } \\
\text { Westring, } 1851\end{array}$ & 8 & 4 & 2 & & 3 & & VI-X & VIII \\
\hline $\begin{array}{l}\text { Clubiona pallidula } \\
\text { (Clerck, 1757) }\end{array}$ & 3 & & 1 & & 1 & & $\mathrm{~V}, \mathrm{IX}, \mathrm{X}$ & \\
\hline $\begin{array}{l}\text { Clubiona phragmitis } \\
\text { C. L. Koch, } 1843\end{array}$ & & & 1 & & & & IX & \\
\hline $\begin{array}{l}\text { Clubiona stagnatilis } \\
\text { Kulczyñski, } 1897\end{array}$ & & & 1 & & 4 & & III,IV,X & \\
\hline $\begin{array}{l}\text { Clubiona subsultans } \\
\text { Thorell, } 1875\end{array}$ & 2 & & 12 & & 3 & & $I X, X$ & \\
\hline \multicolumn{9}{|l|}{ Dictynidae } \\
\hline $\begin{array}{l}\text { Lathys humilis } \\
\text { (Blackwall, 1855) }\end{array}$ & 1 & & & & & & VII & \\
\hline $\begin{array}{l}\text { Lathys stigmatisata } \\
\text { (Menge, 1869) }\end{array}$ & 1 & & & & & & VI & \\
\hline \multicolumn{9}{|l|}{ Gnaphosidae } \\
\hline $\begin{array}{l}\text { Haplodrassus cognatus } \\
\text { (Westring, 1861) }\end{array}$ & 1 & & 2 & & 4 & & $\mathrm{~V}, \mathrm{VI}, \mathrm{VIII}, \mathrm{X}$ & \\
\hline $\begin{array}{l}\text { Haplodrassus signifier } \\
\text { (C. L. Koch, 1839) }\end{array}$ & & & & & 1 & & III & \\
\hline \multicolumn{9}{|l|}{ Linyphiidae } \\
\hline $\begin{array}{l}\text { Agyneta conigera } \\
\text { (O. P. Cambridge, 1863) }\end{array}$ & & & & & 1 & & VIII & \\
\hline $\begin{array}{l}\text { Agyneta innotabilis } \\
\text { (O. P. Cambridge, 1863) }\end{array}$ & 1 & & & & 1 & & $\mathrm{~V}, \mathrm{VII}$ & \\
\hline $\begin{array}{l}\text { Drapetisca socialis } \\
\quad \text { (Sundevall, 1833) }\end{array}$ & 25 & 13 & 8 & 12 & 14 & 10 & IV,VII-X & VI-VIII \\
\hline $\begin{array}{l}\text { Entelecara erythropus } \\
\text { (Westring, 1851) }\end{array}$ & & & & & 1 & & V & \\
\hline $\begin{array}{l}\text { Helophora insignis } \\
\text { (Westring, 1851) }\end{array}$ & & & & & 1 & & VIII & \\
\hline
\end{tabular}




\begin{tabular}{|c|c|c|c|c|c|c|c|c|}
\hline & \multicolumn{2}{|c|}{ Ac } & \multicolumn{2}{|c|}{ Olh } & \multicolumn{2}{|c|}{$\mathrm{Rf}$} & \multicolumn{2}{|c|}{ Months } \\
\hline & $\mathrm{ad}$ & juv & ad & juv & ad & juv & ad & juv \\
\hline $\begin{array}{l}\text { Labulla thoracica } \\
\text { (Wider, 1834) }\end{array}$ & 3 & 9 & 3 & 6 & 7 & 13 & VIII-X & VI-VIII \\
\hline $\begin{array}{l}\text { Lepthyphantes minutus } \\
\text { (Blackwall, 1833) }\end{array}$ & 20 & & 7 & & 4 & & VIII-X & \\
\hline $\begin{array}{l}\text { Lophomma punctatum } \\
\text { (Blackwall, 1841) }\end{array}$ & 1 & & 1 & & & & $\mathrm{III}, \mathrm{X}$ & \\
\hline $\begin{array}{l}\text { Moebelia penicillata } \\
\text { (Westring, 1851) }\end{array}$ & & & 1 & & & & III & \\
\hline $\begin{array}{l}\text { Neriene clathrata } \\
\text { (Sundevall, 1830) }\end{array}$ & & & 1 & & & & $\mathrm{VI}$ & \\
\hline $\begin{array}{l}\text { Neriene montana } \\
\quad(\text { Clerck, 1757) }\end{array}$ & 18 & 70 & & & 3 & 17 & V-VII & III,IV, VI-X \\
\hline $\begin{array}{l}\text { Neriene peltata } \\
\text { (Wider, 1834) }\end{array}$ & & & & & 1 & & $\mathrm{VI}$ & \\
\hline $\begin{array}{l}\text { Pityohyphantes phrygianus } \\
\text { (C. L. Koch, 1836) }\end{array}$ & & 1 & & & & & & III \\
\hline $\begin{array}{l}\text { Porrhomma pygmaeum } \\
\text { (Blackwall, 1834) }\end{array}$ & 10 & & & & & & $\mathrm{III}-\mathrm{V}, \mathrm{X}$ & \\
\hline \multicolumn{9}{|l|}{ Lycosidae } \\
\hline $\begin{array}{l}\text { Piratula hygrophila } \\
\text { (Thorell, 1872) }\end{array}$ & & & & & 2 & & $\mathrm{VI}$ & \\
\hline \multicolumn{9}{|l|}{ Salticidae } \\
\hline $\begin{array}{l}\text { Pseudicius encarpatus } \\
\text { (Walckenaer, 1802) }\end{array}$ & & & 1 & & & & V & \\
\hline \multicolumn{9}{|l|}{ Segestriidae } \\
\hline $\begin{array}{l}\text { Segestria senoculata } \\
\text { (Linnaeus, 1758) }\end{array}$ & 15 & 76 & 6 & 33 & 2 & 24 & III-X & III-X \\
\hline \multicolumn{9}{|l|}{ Tetragnathidae } \\
\hline $\begin{array}{l}\text { Metellina merianae } \\
\text { (Scopoli, 1763) }\end{array}$ & & & & & 1 & & IX & \\
\hline $\begin{array}{l}\text { Metellina segmentata } \\
\quad(\text { Clerck, 1757) }\end{array}$ & & & & & 1 & & IX & \\
\hline $\begin{array}{l}\text { Pachygnatha clercki } \\
\text { Sundevall, } 1823\end{array}$ & 6 & 1 & & & & & III,IV & $x$ \\
\hline \multicolumn{9}{|l|}{ Theridiidae } \\
\hline $\begin{array}{l}\text { Enoplognatha ovata } \\
\text { (Clerck, 1757) }\end{array}$ & & & 1 & & 1 & & $\mathrm{VI}$ & \\
\hline $\begin{array}{l}\text { Platnickina tincta } \\
\quad \text { (Walckenaer, 1802) }\end{array}$ & 2 & & & & & & $\mathrm{VII}, \mathrm{X}$ & \\
\hline $\begin{array}{l}\text { Steatoda bipunctata } \\
\text { (Linnaeus, 1758) }\end{array}$ & 9 & 18 & 7 & 14 & 4 & 7 & IV $-\mathrm{X}$ & $\mathrm{V}-\mathrm{X}$ \\
\hline $\begin{array}{l}\text { Theridion mystaceum } \\
\text { L. Koch, } 1870\end{array}$ & 7 & & 5 & & 11 & & V-VII & \\
\hline $\begin{array}{l}\text { Theridion varians } \\
\text { Hahn, } 1833\end{array}$ & & & 1 & & & & V & \\
\hline \multicolumn{9}{|l|}{ Thomisidae } \\
\hline $\begin{array}{l}\text { Diaea dorsata } \\
\quad \text { (Fabricius, 1777) }\end{array}$ & & 15 & & 41 & 1 & 12 & $x$ & III, IX,X \\
\hline $\begin{array}{l}\text { Ozyptila praticola } \\
\text { (C. L. Koch, 1837) }\end{array}$ & & & & & 1 & & V & \\
\hline Total no. of individuals & 208 & 431 & 218 & 471 & 89 & 139 & & \\
\hline Total no. of species & & & & & & & & \\
\hline Total no. of exclusive sp. & & & & & & & & \\
\hline
\end{tabular}


silver birch Betula pendula and spruce and two hornbeams. The material of each month from each plot was combined as one sample, irrespective of tree species, because of the low abundance of spiders on the examined tree trunks. This yielded in total 19 samples from each plot, i.e. forest type.

Some spider species are identifiable only as adults, others are also easy to identify as juveniles. Thus, including into analyses all specimens identified to the species level may cause a bias (overrepresentation of the easy identifiable species). To avoid this problem, we included into all our statistics, including the Shannon index, only adult specimens identified to the species level. Spider nomenclature is used according to the World Spider Catalog (2017).

Spider species diversity was calculated using the Shannon diversity index:

$H^{\prime}=-\Sigma p_{\mathrm{i}} \ln p_{\mathrm{i}}$

where $p_{\mathrm{i}}$ is the proportion of individuals belonging to species $i$.

To assess associations of the numbers of collected spider individuals and species with the forest types and sampling periods, the General linear models (GLM) were used (Miller \& Haden 2006). The "forest type" (alder carr, ash-alder riparian forest, oak-lime-hornbeam forest) "month" (eight months from March to October) and "year" (three years of study) were treated as fixed categorical explanatory variables. Both models (i.e. for the number of individuals and the number of species) included also interactions between the above mentioned variables, except the one among all the three fixed explanatory variables because of the lack of replicates, i.e. there is only one sample from each forest type of each month and year. Moreover, in the case of GLM assessing the associations of the variables with the number of spider species we included in the analysis log-transformed "number of individuals" as a continuous explanatory variable, in order to assess whether possible differences in the number of species can be explained by differences in the numbers of collected individuals. If GLM revealed a significant effect of a given variable, Tukey's post hoc test was used to evaluate the differences between the levels of the fixed ex-
Table 2. Results of the GLM analysis assessing association of month, forest type (alder carr, ash-alder riparian forest, oak-lime-hornbeam forest) and year with the number of collected spider individuals.

\begin{tabular}{lrrr}
\hline Variable & $d f$ & $F$ & $p$ \\
\hline Month & 7 & 16.80 & $<0.001$ \\
Forest type & 2 & 20.75 & $<0.001$ \\
Year & 2 & 7.64 & 0.004 \\
Month $\times$ Forest type & 14 & 3.49 & 0.007 \\
Month $\times$ Year & 9 & 2.32 & 0.061 \\
Forest type $\times$ Year & 4 & 2.42 & 0.086 \\
Error & 18 & & \\
& & &
\end{tabular}

planatory variable. Statistical analyses were conducted using the STATISTICA 12.0 program (StatSoft Inc. 2015). The results with $p<0.05$ were considered statistically significant.

\section{Results}

A total of 2,182 spider individuals belonging to 14 families were collected during our study: 853 in alder carr, 888 in oak-lime-hornbeam forest and 441 in ash-alder riparian forest, but we identified to the species level 639, 689, and 228 specimens, respectively. Among the spiders identified to the species level, the adult individuals were: 208 in alder carr, 218 in oak-lime-hornbeam forest and 89 in ash-alder riparian forest (Table 1).

Altogether, we found 43 spider species (three of them were identified only as juveniles) but only 14 species were common to the three analysed forest types. We found 26 species in alder carr (including 9 species recorded exclusively there), 23 in oak-lime-hornbeam forest (6 exclusive species) and 27 in ash-alder riparian forest (9 exclusive species). Taking into account only adult specimens, we found 23 species in alder carr, 21 in oak-lime-hornbeam forest and 27 in ash-alder riparian forest (Table 1).

The most numerous species in the oak-limehornbeam forest as well as in the alder carr was Amaurobius fenestralis, whereas Anyphaena accentuata was the most abundant species in the ash-alder riparian forest. However, taking into consideration only adult specimens changed the most numerous species in ash-alder riparian forest as Drapetisca socialis. Of the 43 species re- 
Fig. 2. Least squares means ( $\pm \mathrm{SE}$ ) (from the statistical model of Table 3) of the numbers of spider individuals collected during the study months in the three forest types in the Białowieża National Park. a: months in oak-lime-hornbeam forest, which differ from the month indicated by letter $\mathrm{b}$ (Tukey's post hoc test, $p=$ 0.029 ), but not with each other. $c$ and $\mathrm{d}$ : months that differ from each other in alder carr (Tukey's post hoc test, $p=0.043$ ). Months without letters do not differ from other months.

Fig. 3. The relationship between logtransformed number of individuals and number of spider species collected in the Białowieża National Park.
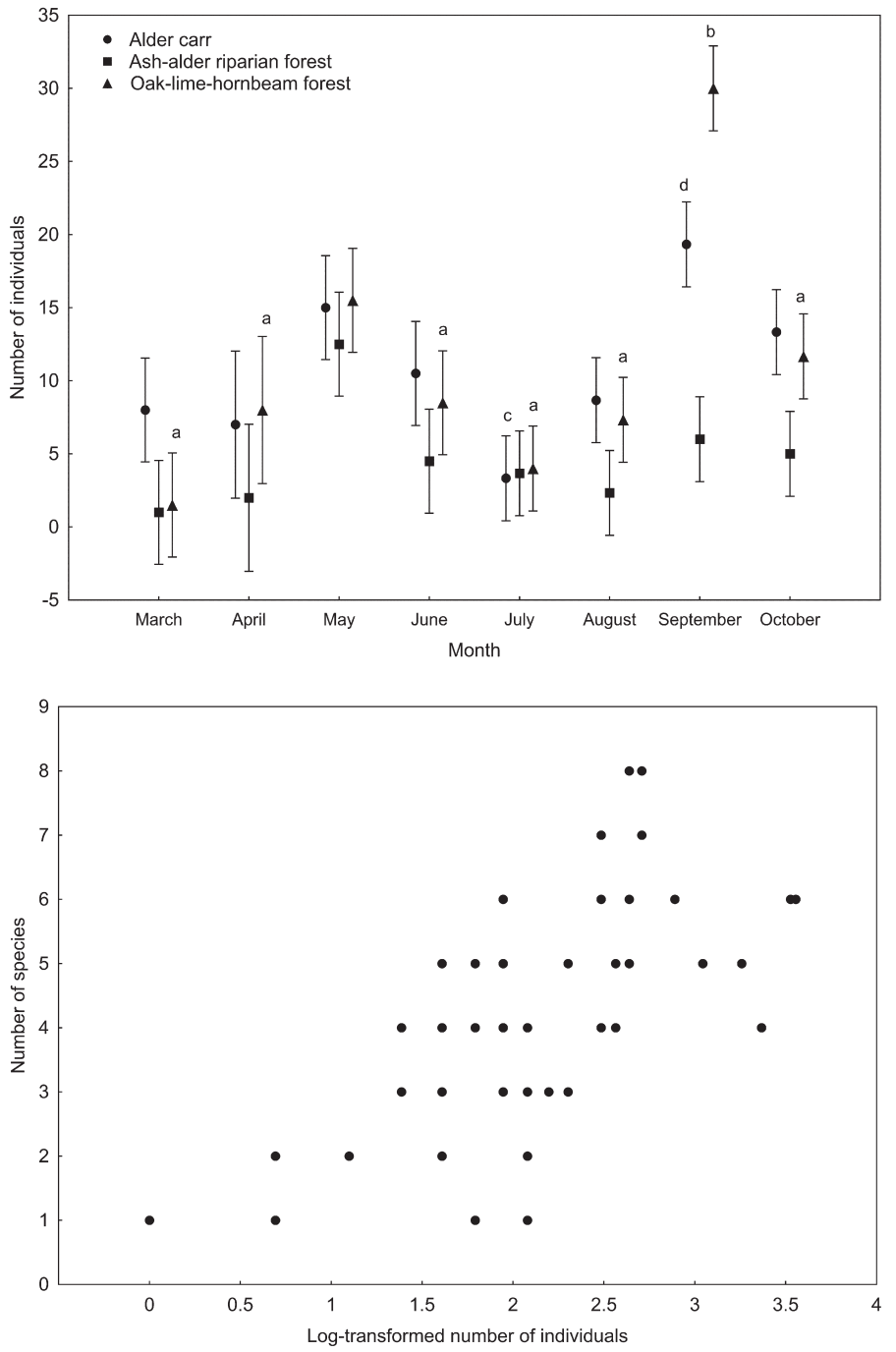

corded on tree trunks, only four (A. fenestralis, $A$. accentuata, Segestria senoculata and Neriene montana) were collected in each analysed month. Most of the species were recorded in small numbers (one or two specimens) or even if they were collected in larger numbers, they were found only in a few months (Table 1).

The highest species diversity, calculated for the whole study period, was recorded in ash-alder riparian forest $\left(H^{\prime}=2.87\right)$, lower in alder carr $\left(H^{\prime}\right.$ $=2.45)$ and the lowest in oak-lime-hornbeam forest $\left(H^{\prime}=1.75\right)$.

The number of spider individuals collected during our study depended on the sampling month, year and the forest type, but not straightforwardly so, because there was also a significant interaction between month and forest type (Table 2). On average, we found two times less spider individuals in one sample in the ash-alder riparian forest (least squares mean $4.5 \pm 1.27 \mathrm{SE}$ ) compared to the alder carr $(10.8 \pm 1.27)$ and oak-limehornbeam forest $(11.3 \pm 1.27)$ and the differences between the first and the two latter habitats were statistically significant (Tukey post hoc test, $p<$ 0.001 ). The most spider individuals we caught in the second year of the study (least squares mean $11.8 \pm 1.36 \mathrm{SE})$, less in the first year $(7.4 \pm 1.53)$ and the least in the third year $(7.5 \pm 1.09)$. The differences between the first and the second year and between the second and the third year were statistically significant (Tukey post hoc test, $p=$ 0.016). Generally, the largest number of adult 
Table 3. Results of the GLM analysis assessing association of number of individuals, month, forest type (alder carr, ash-alder riparian forest, oak-lime-hornbeam forest) and year with the number of collected spider species.

\begin{tabular}{lrrr}
\hline Variable & $d f$ & \multicolumn{1}{c}{$F$} & \multicolumn{1}{c}{$p$} \\
\hline Number of individuals & 1 & 99.70 & $<0.001$ \\
Month & 7 & 0.72 & 0.657 \\
Forest type & 2 & 4.74 & 0.023 \\
Year & 2 & 0.38 & 0.692 \\
Month $\times$ Forest type & 14 & 0.83 & 0.614 \\
Month $\times$ Year & 9 & 1.27 & 0.323 \\
Forest type $\times$ Year & 4 & 1.02 & 0.424 \\
Error & 17 & & \\
\hline
\end{tabular}

specimens per sample was collected in September and the smallest one in March. However, taking into consideration forest types, the most adult specimens in alder carr and oak-lime-hornbeam forest were collected in September whereas in ash-alder riparian forest in May. The smallest number of spider specimens in alder carr was found in July whereas in March in the two other forests (Fig. 2).

The number of collected spider species depended, as expected, positively on the number of spider individuals, i.e. the sample size (Fig. 3), and forest type (Table 3). The number of spider species per sample was the highest in alder carr (least squares mean $4.2 \pm 0.31 \mathrm{SE}$ ), lower in the ash-alder riparian forest $(3.9 \pm 0.35)$ and the lowest in oak-lime-hornbeam forest $(3.0 \pm 0.30)$. The differences between the first and the two latter habitats were statistically significant (Tukey post hoc test, $p=0.022$ ).

\section{Discussion}

In general, spider species collected on tree trunks can be divided into two main groups: spiders living constantly on the tree trunks (on the bark or under the bark) and spiders for which trunks are a temporary habitat (Wunderlich 1982, Horváth \& Szinetár 2002). Spiders from the first group can be found on the tree trunks during the whole year, whereas those from the second group live also in other habitats besides trunks and visit the bark sporadically or for overwintering. Based on our research, we can make the same division of spi- ders collected on the tree trunks. We identified 43 spider species in three analysed forest types but most of them were collected occasionally. Some of the species (e.g. Haplodrassus signifer, Pityohyphantes phrygianus, Lophomma punctatum) were found only in March when winter still prevails in the Białowieża National Park and/or in October when winter was approaching, which shows that tree trunks serve these species only as a wintering place (Hänggi et al. 1995).

Other species, even though recorded on the tree trunks in several analysed months, were collected in small numbers (e.g. Clubiona lutescens, Neriene peltata). This shows that tree trunks serve them as temporary or accidental habitats where they can find prey or shelter (Szinetár \& Horváth 2005).

Finally, four species were collected regularly in large numbers during the whole trapping period, i.e. in each month from March to October: $A$. fenestralis, $A$. accentuata, $S$. senoculata, and $N$. montana. This clearly shows that tree trunks are a common habitat for these species, even though they do not live exclusively on the bark (Wunderlich 1982). Other authors also reported the first three species as abundant trunk-dwellers as Horváth and Szinetár (1998) found A. fenestralis, $A$. accentuata, and $S$. senoculata the most frequent bark-dwelling spiders on black pine (Pinus nigra). Blick (2011) listed $A$. fenestralis and $A$. accentuata among the twenty most abundant bark spider species in Germany. In their study conducted in the Czech Republic, Machač and Tuf (2016) found $A$. accentuata to be one of the most abundant spider species, both in a town and in the surrounding floodplain forest. The fourth abundant species in our study, N. montana, was recorded by some authors on the trunks but in small numbers (Koponen 2008, Machač \& Tuf 2016).

Besides the above-mentioned species, we found other typical tree bark spiders: Nuctenea umbratica, Haplodrassus cognatus, Agyneta innotabilis, D. socialis, Moebelia penicillata, Pseudicius encarpatus, Steatoda bipunctata and Theridion mystaceum, although some of them were not numerous. Szinetár and Horváth (2005) categorized them as exclusive bark-dwelling species or facultative bark-dwellers with a close relationship with tree trunks. 
In our research, we collected a few species that have not been mentioned in the literature devoted to the bark-dwelling spiders (e.g. Szinetár \& Horváth 2005, Koponen 2008, Machač \& Tuf 2016): Clubiona phragmitis, Lathys stigmatisata, H. signifer, Helophora insignis, L. punctatum, Pachygnatha clercki and Metellina segmentata. Clubiona phragmitis and $M$. segmentata are species living in the herb and bush layer and the rest are typical ground dwelling spiders. All these spiders seem to be accidental on tree trunks, because other microhabitats are the typical for them (Hänggi et al. 1995).

It is worth to mention that in each type of investigated forest we caught Coelotes atropos, a species that seems to be common in the primeval forests in the ground layer and under the bark (Sechterová 1992, Stańska et al. 2016).

Our study revealed differences in spider abundance and number of species among the three analysed types of forests. On average, samples from the alder carr and oak-lime hornbeam forest contained twice as many spider individuals as the samples from the ash-alder riparian forest. In spite of the lowest number of individuals in the ash-alder riparian forest, the highest species diversity ( $H^{\prime}$ calculated for the whole study period) was found there, and the lowest species diversity and total number of species were in the oak-lime-hornbeam forest. Moreover, there were also differences in the species composition and abundance of particular spider species between the forest types. Of all the collected spider species, only one third was common to the three types of forest. The most abundant species in the oak-lime-hornbeam forest and in the alder carr, i.e. A. fenestralis, accounted for only a few individuals in the ash-alder riparian forest (Table 1). In our opinion, one of the likely reasons of such a result is the placement of the traps on the different tree species in the three analysed forests (unfortunately, tree species could not be included in the analysis because the material was combined from all the traps of each plot). The study of Mupepele et al. (2014), using insecticide fogging in the canopy of the managed part of Białowieża Forest and three different forests, showed that the spider communities were tree-species specific. This phenomenon was observed for black alder, hornbeam, spruce and Scots pine. In their re- search on spider communities in forest canopies, Korenko et al. (2011) found that spider species richness and abundance were higher on coniferous than deciduous trees. They also found differences across deciduous tree species, as both the abundance and species richness were significantly higher on black alder than on two oak species.

The variation in spider assemblages living on trunks of different tree species can be explained, among other things, by differences in the bark structure. Trunks with structurally more complex bark are more attractive for spiders than trunks with smooth bark (Curtis \& Morton 1974, Nicolai 1986). Prinzing $(2001,2005)$ showed that the distribution of bark-dwelling arthropods is significantly modified by microclimatic conditions (e.g. temperature, humidity) prevailing on trunks and arthropods are able to respond to the fluctuations in these conditions by, for example, compensatory redistribution within the mosaic pattern of microhabitats on trunks.

The next reason for the differences in spider assemblages between the three forest types may result from differences in general environmental parameters (not only those directly related to trunks) and the habitat structure within particular forest types. Many studies have shown that arboreal spider communities are shaped by, among other things, humidity, ground vegetation, forest floor structure, the presence of woody debris, canopy openness and the type of litter, which partly result from the tree species growing in particular forests (Ziesche \& Roth 2008, Castro \& Wise 2009, Košulič et al. 2016, Stańska et al. 2016). The three types of forests analysed in our study differed considerably in a number of these factors. For example, both the alder carr and the riparian forest were more humid than the oaklime-hornbeam forest. Moreover, the vegetation of the forest floor was poorer in the oak-limehornbeam forest and luxuriant in the ash-alder riparian forest, which probably affected the number of collected spider individuals. The hummock-hollow structure of the alder carr and water stagnating between trees over a long period of the year probably increase the importance of trunks both as a place of living and as a refuge allowing spiders to wait for the end of the flooding period.

Our study revealed that the number of spider 
individuals changed among months and years during the sampling period. The reasons may be partially the same as in the case of differences between the forest types, but with changes among the seasons of the year. Such factors, as vegetation structure, insolation or humidity change over the season and can vary from year to year. This may cause that during some periods of the year tree trunks may become an attractive habitat for spiders, where they can find prey or shelters from unfavorable environmental conditions. Changes in the use of tree trunks may also result from the phenology of particular spider species.

In conclusion, the spider fauna of tree trunks differed between the three analysed forest types in the number of individuals and the species composition. In our opinion, the differences probably result from different tree species on which the traps were located and from different environmental conditions in the particular forest types. Of the 43 recorded species, only some were regularly collected during the whole study period ( $A$. fenestralis, $A$. accentuata, $S$. senoculata, and $N$. montana), whereas for most species tree trunks were temporary or accidental habitats.

Acknowledgements. We would like to thank the authorities of the Białowieża National Park for their kind help during conducting our research. We also would like to thank two anonymous reviewers for their suggestions and comments that were very helpful in improving the manuscript. The results of the research carried out under the research theme No. 222/05/S were financed from the science grant granted by the Ministry of Science and Higher Education and by State Committee for Scientific Research (grant 6P04G01417).

\section{References}

Blick, T. 2011: Abundant and rare spiders on tree trunks in German forests (Arachnida, Araneae). - Arachnologische Mitteilungen 40: 5-14.

Bobiec, A. 2002: Living stands and dead wood in the Białowieża forest: suggestions for restoration management. - Forest Ecology and Management 165: 125-140.

Bogya, S., Szinetár, C. \& Markó, V. 1999: Species composition of spider (Araneae) assemblages in apple and pear orchards in the Carpathian Basin. - Acta Phytopathologica et Entomologica Hungarica 34: 99-121.

Castro, A. \& Wise, D. H. 2009: Influence of fine woody debris on spider diversity and community structure in forest leaf litter. - Biodiversity Conservation 18 : 3705-3731.
Curtis, D. J. \& Morton, E. 1974: Notes on spiders from tree trunks of different bark texture; with indices of diversity and overlap. - Bulletin of the British Arachnological Society 3: $1-5$.

Floren, A. 2008: Abundance and ordinal composition of arboreal arthropod communities of various trees in old primary and managed forests. - In: Floren, A. \& Schmidl, J. (eds), Canopy arthropod research in Europe: 279-298. Bioform Entomology, Nuremberg. 576 pp.

Gutowski, J. M. \& Jaroszewicz, B. 2004: Puszcza Białowieska jako ostoja europejskiej fauny owadów. Białowieża Primeval Forest as a refuge of the European entomofauna. - Wiadomości entomologiczne 23: 67-87. [in Polish with English abstract.]

Hänggi, A., Stöckli, E. \& Nentwig, W. 1995: Habitats of Central European spiders. - Centre suisse de cartographie de la faune (CSCF) Neuchâtel, 460 pp.

Horváth, R. \& Szinetár, C. 1998: Study of the bark-dwelling spiders (Araneae) on black pine (Pinus nigra) I. — Miscellanea Zoologica Hungarica 12: 77-83.

Horváth, R. \& Szinetár, C. 2002: Ecofaunistical study of bark-dwelling spiders (Araneae) on black pine (Pinus nigra) in urban and forest habitats. - Acta Biologica Debrecina 24: 87-101.

Horváth, R., Lengyel, S., Szinetár, C. \& Honti, S. 2004: The effect of exposition time and temperature on spiders (Araneae) overwintering on the bark of black pine (Pinus nigra). — In: Samu, F. \& Szinetár, C. (eds), European Arachnology 2002: proceedings of the $20^{\text {th }} \mathrm{Eu}-$ ropean Colloquium of Arachnology: 95-102. Plant Protection Institute and Berzsenyi College, Budapest. $356 \mathrm{pp}$.

Horváth, R., Lengyel, S., Szinetár, C. \& Jakab, L. 2005: The effect of prey availability on spider assemblages on European black pine (Pinus nigra) bark: spatial patterns and guild structure. - Canadian Journal of Zoology 83: 324-335.

Karpiński, J. J. 1956: Pająki (Araneida) w Biocenozie Białowieskiego Parku Narodowego. - Roczniki Nauk Leśnych 14: 29-47. [In Polish.]

Koponen, S. 2004: Arthropods from high oak branches comparison of two trap types, with a special reference to spiders. - Latvijas Entomologs 41: 71-75.

Koponen, S. 2008: Spiders from groves in the southwestern archipelago of Finland (Araneae). — Revista Ibérica de Aracnología 15: 97-104.

Koponen, S., Rinne, V. \& Clayhills, T. 1997: Arthropods on oak branches in SW Finland, collected by a new trap type. - Entomologica Fennica 8: 177-183.

Korenko, S. \& Pekár, S. 2010: Is there intraguild predation between winter-active spiders (Araneae) on apple tree bark? - Biological Control 54: 206-212.

Korenko, S., Kula, E., Šimon, V., Michalková, V. \& Pekár, S. 2011: Are arboreal spiders associated with particular tree canopies? - Nort-Western Journal of Zoology 7: 261-269.

Koślińska, M. 1967: Badania nad fauną zimującą pod korą i w korze jabłoni. Część II. Badania nad pajęczakami 
(Arachnida) - Polskie Pismo Entomologiczne, 37: 587-602. [In Polish.]

Košulič, O., Michalko, R. \& Hula, V. 2016: Impact of canopy openness on spider communities: implications for conservation management of formerly coppiced oak forests. - PLoS ONE 11(2): e0148585. doi:10. 1371/journal.pone.0148585.

Łęgowski, D. 2001: Waloryzacja lasów Puszczy Białowieskiej metodą zooindykacyjną na podstawie pająków (Aranei). — In: Szujecki, A. (ed.), Próba szacunkowej waloryzacji lasów Puszczy Białowieskiej metodą zooindykacyjną: 207-233. Wydawnictwo SGGW, Warszawa. 419 pp. [In Polish.]

Machač, O. \& Tuf, I. H. 2016: Spiders and harvestmen on tree trunks obtained by three sampling methods. Arachnologische Mitteilungen 51: 67-72.

Michel, A. K. \& Winter, S. 2009: Tree microhabitat structures as indicators of biodiversity in Douglas-fir forests of different stand ages and management histories in the Pacific Northwest, U.S.A. - Forest Ecology and Management 257: 1453-1464.

Miller, J. \& Haden, P. 2006: Statistical Analysis with the General Linear Model. Creative Commons Attribution. $259 \mathrm{pp}$.

Mupepele, A. C., Müller, T., Dittrich, M. \& Floren, A. 2014: Are temperate canopy spiders tree-species specific? — PLoS ONE 9(2): e86571. doi:10.1371/journal.pone.0086571.

Nicolai, V. 1986: The bark of trees: thermal properties, microclimate and fauna. - Oecologia 69: 148-160.

Nicolai, V. 1989: Thermal properties and fauna on the bark of trees in two different African ecosystems. - Oecologia 80: 421-430.

Nicolai, V. 1993: The arthropod fauna on the bark of deciduous and coniferous trees in a mixed forest in the Itasca State Park, MN, USA. - Spixiana 16: 61-69.

Nicolai, V. 1995: The ecological significance of trees' bark during ecosystem dynamics. - Spixiana 18 : 187-199.

Okołów, C., Karaś, M. \& Bołbot, A. 2009: Białowieża National Park, know it, understand it, protect it. Białowieski Park Narodowy, Białowieża. 240 pp.

Otto, S. \& Floren, A. 2007: The spider fauna (Araneae) of tree canopies in the Białowieża Forest. — Fragmenta Faunistica 50: 57-70.

Pawlaczyk, P. 2009: Forest communities. — In: Okołów, C., Karaś, M. \& Bołbot, A. (eds), Białowieża National Park. Know it - Understand it - Protect it: 37-58. Białowieski Park Narodowy, Białowieża. 240 pp.

Pekár, S. 1999: Some observations on overwintering of spiders (Araneae) in two contrasting orchards in the Czech Republic. - Agriculture, Ecosystems and Environment 73: 205-210.

Prinzing, A. J. 2001: Use of shifting microclimatic mosaics by arthropods on exposed tree trunks. - Annals of the Entomological Society of America 94: 210-218.

Prinzing, A. 2005: Corticolous arthropods under climatic fluctuations: compensation is more important than migration. - Ecography 28: 17-28.

Regnery, B., Paillet, Y., Couvet, D. \& Kerbiriou, C. 2013 :
Which factors influence the occurrence and density of tree microhabitats in Mediterranean oak forests? Forest Ecology and Management 295: 118-125.

Sechterová, E. 1992: On the biology of species of the genus Coelotes (Araneae, Agelenidae) in central European mountains. - Acta Entomologica Bohemoslovaca 89: $337-349$.

Sebek, P., Vodka, S., Bogusch, P., Pech, P., Tropek, R., Weiss, M., Zimova, K. \& Cizek, L. 2016: Open-grown trees as key habitats for arthropods in temperate woodlands: The diversity, composition, and conservation value of associated communities. — Forest Ecology and Management 380: 172-181.

Stańska, M. 2007: Rare and threatened spider species (Araneae) in selected types of deciduous forests in the Białowieża Forest. - Nature Conservation 64: 13-29.

Stańska, M., Stański, T., Gładzka, A. \& Bartos, M. 2016: Spider assemblages of hummocks and hollows in a primeval alder carr in the Białowieża National Park effect of vegetation structure and soil humidity. - Polish Journal of Ecology 64: 564-577.

Staręga, W. \& Kupryjanowicz, J. 2001: Subclassis (podgromada): Araneae - pająki. — In: Gutowski, J. M. \& Jaroszewicz, B. (eds), Katalog Fauny Puszczy Białowieskiej: 55-63. Instytut Badawczy Leśnictwa, Warszawa. 404 pp. [In Polish.]

Szinetár, C. \& Horváth, R. 2005: A review of spiders on tree trunks in Europe (Araneae). - In: Deltshev, C. \& Stoev, P. (eds), European Arachnology 2005, Acta zoologica bulgarica, Suppl. No. 1: 221-257. Institute of Zoology and National Museum of Natural History, Bulgarian Academy of Sciences, Blagoevgrad. 343 pp.

Tomiałojć, L. 1991: Characteristics of old growth in the Białowieża Forest, Poland. — Natural Areas Journal 11: 7-18.

Wardhaugh, C. W., Edwards, W. \& Stork, N. E. 2013: Body size variation among invertebrates inhabiting different canopy microhabitat: flower visitors are smaller. - Ecological Entomology 38: 101-111.

Weiss, I. 1995: Spinnen und Weberknechte auf Baumstämmen im Nationalpark Bayerischer Wald. - In: Růžička, V. (ed.), Proceedings of the $15^{\text {th }}$ European Colloquium of Arachnology: 184-192. Czech Academy of Sciences, Institute of Entomology, České Budějovice. $238 \mathrm{pp}$.

Wesołowski, T. 2007: Primeval conditions - what can we learn from them? - Ibis 149: 64-77.

World Spider Catalog 2017: World Spider Catalog, version 18.0. Natural History Museum Bern. [www document]. URL http://wsc.nmbe.ch. (Site visited on 21 April 2017).

Wunderlich, J. 1982: Mitteleuropäische Spinnen (Araneae) der Baumrinde. - Zeitschrift für angewandte Entomologie 94: 9-21.

Ziesche, T. M. \& Roth, M. 2008: Influence of environmental parameters on small-scale distribution of soil-dwelling spiders in forests: what makes the difference, tree species or microhabitat? - Forest Ecology and Management 255: 738-752. 